\title{
Familiepolitikk og farsroller
}

Hvert 17. sekund kommer et barn til verden i Russland, men litt oftere, hvert 16. sekund, er det noen som dør. ${ }^{1}$ Etter tre år med naturlig befolkningsvekst, er dermed trenden på ny negativ. Også den tredje faktoren som avgjør den demografiske utviklingen, migrasion, er i endring. Russland har i mange år hatt høy innvandring, men migrasjonen ser nå ut til å avta $\mathrm{i}$ takt med at den økonomiske situasjonen forverrer seg. Russlands demografiske utfordring er altså langt fra løst.

Demografi har i lengre tid stått høyt på Kremls politiske agenda, og i 2006 definerte Vladimir Putin til og med den demografiske krisen som en «sikkerhetstrussel». Måten de demografiske utfordringene håndteres på påvirker ikke bare landets langsiktige utvikling, men sier også noe om Russland av i dag. I den offisielle retorikken kommer demografidiskursen oftest til uttrykk i sammenheng med familiepolitikken. Det er flere grunner til det: Migrasjonsspørsmålet er betent. Folkehelse og livsstil endres sakte. Fokus på barnefødsler kan dermed på kort sikt være den mest effektive måten «å lege fortidens demografiske sår» på, slik Putin formulerte det i sin årlige tale til Den føderale forsamlingen i 2015. Russiske myndigheter har investert betydelige ressurser for å øke fødselstallene, blant annet med utbetaling av såkalte mødrepenger (materinskij kapital) til kvinner med to eller flere barn, et midlertidig program som nylig ble forlenget med ytterligere to år.

Det er nok ingen tilfeldighet at myndighetene snakker om utbetaling av penger til mor - mødre og barn står i sentrum for den russiske familiepolitikken, mens farsrollen, slik Pelle Åberg påpeker i sin artikkel i denne utgaven av Nordisk Østforum, knapt omtales. Tradisjonelle kjønnsroller har større aksept blant russiske menn og kvinner enn det som er tilfellet i Norden. Det er i en slik kontekst Putin har profilert seg som en macho-mann, mens hans rolle som far ikke blir betonet overhodet. Åberg ser på normer for farskap i historisk kontekst, og argumenterer for at Sovjetunionen gradvis tok over rollen som familieforsørger, noe som førte til at far gikk fra å ha en klar rolle som familiens overhode til en heller marginalisert posisjon. De uklare rammene for farsrollen har satt spor også i dagens familiepolitikk.

Men Russland - som alle andre samfunn - er selvsagt ikke statisk og entydig. Åberg skriver at farskap i Russland i dag er en arena for konkurrerende diskurser, og pappaens fravær i den statlige diskursen står i kontrast til idealet om den pålitelige familieforsørgeren som for eksempel stadig reproduseres i populærkulturen. I tillegg

${ }^{1}$ Tall fra Demoscope Weekly. www.demoscope.ru/weekly/app/popclock/popclock.php. Lesedato 18.3.16. 


\section{KRISTIAN LUNDBY GJERDE OG NATALIA MOEN-LARSEN}

finner forfatteren en alternativ farskapsdiskurs blant den urbane middelklassen, hvor pappaer gis større rom for aktiv deltakelse i barneoppfostringen.

I denne utgavens andre fagartikkel diskuterer Thomas Sedelius Ukrainas politiske utvikling siden 1990-tallet med utgangspunkt i regimetyper. Sedelius argumenterer for at tilfellet Ukraina i noen grad støtter den statsvitenskapelige litteraturens advarsler om risikoen ved semipresidentialisme. Samtidig mener han det er grobunn for fortsatt demokratisk utvikling - og nye grunnlovsendringer. I den tredje artikkelen gir Kristian Åtland en grundig gjennomgang av den russiske kystvakten med blikk både på organisering og operativ virksomhet, herunder samarbeid med andre lands kystvakter.

Vi bringer også en rekke omtaler av aktuelle bøker, blant annet om russisk historie, forholdet mellom Norge og Russland, virkningen av sanksjonene mot Russland, og om sosiale bevegelser i urbane strøk i Øst-Europa.

God lesning!

Kristian Lundby Gjerde og Natalia Moen-Larsen 